\title{
The Research about Effects of Borrowing on the Firm's Profitability
}

\author{
Liyang Jiang ${ }^{1, a}$ \\ ${ }^{1}$ School of Business management, Tonghua Normal University, China \\ adbcy9999@163.com
}

Keywords: earnings per share; capital structure decision; earnings before interest and tax; recapitalization decision; benefit

Abstract. The decision to finance part of the firm's assets with borrowed funds has important managerial implications. If the firm finds it increasingly difficult to service its debt (paying interest and repaying the borrowed funds) because of excessive borrowing, its management will be under pressure to make decisions that may not be in the best interest of shareholders.

\section{Introduction}

In physics, leverage refers to the increase in power that comes from using a lever. In finance, leverage, or gearing, refers to the increase in profitability, usually measured with EPS [1-4] that can come from using debt financing. 1 to see why and how borrowing affects EPS; we examine the Jolly Bear Company (JBC). JBC is currently all-equity financed with 2 million shares outstanding worth $\$ 100$ each. The firm's equity value is thus $\$ 200$ million ( $\$ 100$ times 2 million shares). Because the firm has no debt, the value of its assets is the same as the value of its equity ( $\$ 200$ mil- lion). JBC's chief financial officer, Ms. Johnson, is considering borrowing \$100 million at 10 percent and using the cash to repurchase one-half of the firm's shares at $\$ 100$ per share (we explain later why the share price is not affected by the repurchase). She wants to know how this change in JBC's capital structure might affect the firm's EPS. Table 1 illustrates the effect of this recapitalization decision on EPS for three possible scenarios for the future performance of the economy-recession, expected performance, and expansion.

\begin{tabular}{|c|c|c|c|}
\hline \multicolumn{4}{|c|}{ Current capital structure: no debt and 2 million shares at $\$ 100$ per share } \\
\hline & Recession & Expected & Expansion \\
\hline Earnings before interest and tax (EBIT) & $\$ 10,000,000$ & $\$ 30,000,000$ & $\$ 40,000,000$ \\
\hline Less interest expenses & 0 & 0 & 0 \\
\hline Less tax & 0 & 0 & 0 \\
\hline Equals net earnings & $\$ 10,000,000$ & $\$ 30,000,000$ & $\$ 40,000,000$ \\
\hline Divided by the number of shares & $2,000,000$ & $2,000,000$ & $2,000,000$ \\
\hline Equals earnings per share (EPS) & $\$ 5$ & $\$ 15$ & $\$ 20$ \\
\hline \multicolumn{4}{|c|}{$\begin{array}{l}\text { Proposed capital structure: borrow } \$ 100 \text { million at } 10 \text { percent and use the cash to repurchase } 1 \text { millio } \\
\text { shares at } \$ 100 \text { per share }\end{array}$} \\
\hline & Recession & Expected & Expansion \\
\hline Earnings before interest and tax (EBIT) & $\$ 10,000,000$ & $\$ 30,000,000$ & $\$ 40,000,000$ \\
\hline Less interest expenses & $(10,000,000)$ & $(10,000,000)$ & $(10,000,000)$ \\
\hline Less tax & 0 & 0 & 0 \\
\hline Equals net earnings & $\$ 0$ & $\$ 20,000,000$ & $\$ 30,000,000$ \\
\hline Divided by the number of shares & $1,000,000$ & $1,000,000$ & $1,000,000$ \\
\hline Equals earnings per share (EPS) & $\$ 0$ & $\$ 20$ & $\$ 30$ \\
\hline
\end{tabular}

Table. 1 - JBC's earnings per share under the current and proposed capital structures and in the absence of taxes 


\section{The capital structure decision in a world without taxes and financial distress costs}

Managers can choose from a variety of sources of funds to finance their businesses. Most of these are hybrids of two basic types of capital: debt, such as bank loans and bonds; and equity, which includes retained earnings and common stocks. This paper examines how managers should combine debt and equity financing to establish a capital structure that maximizes the value of the firm's assets and equity. A firm's capital structure is usually identified by its debt ratios, either its debt-to-equity ratio (the amount of borrowing divided by the amount of equity) or its debt-to-assets ratio (the portion of the firm's assets financed with borrowed funds). These two debt ratios are often used interchangeably.

The firm's profit from operations, that is, its earnings before interest and tax [5-8] (EBIT), is not affected by the decision to borrow. Operating profit is $\$ 10$ million under the recession scenario, $\$ 30$ million under the expected performance scenario, and $\$ 40$ million under the expansion scenario, irrespective of the amount of debt Ms. Johnson decides to issue. Consider first the case of the expected scenario. With no debt (upper part of Table 1), net earnings are $\$ 30$ million, the same as EBIT, because there are no interest or tax payments. With 2 million shares outstanding, EPS is equal to $\$ 15$ (\$30 million divided by 2 million shares). With $\$ 100$ million of debt at an interest rate of 10 percent (lower part of Table 1), the interest payment is $\$ 10$ million and net earnings drop to $\$ 20$ million. Before concluding that borrowing has a negative effect, we should examine its impact on EPS. Because there are only 1 million shares after the share repurchase, EPS is now $\$ 20$ (\$20 million divided by 1 million shares). Thus, debt financing boosts expected EPS from $\$ 15$ to $\$ 20$. Financial leverage seems to have the same effect as leverage has in the world of physics. Leverage also works to the advantage of shareholders in the expansion scenario, with EPS rising by 50 percent, from $\$ 20$ to $\$ 30$ (see Table 1). Under the recession scenario, however, EPS, which is positive in the no-debt case, is zero in the borrowing case. We can see this phenomenon graphically by plotting EPS against EBIT for the current and proposed capital structure, as shown in Figure 1. The no-debt line starts at the origin because EPS is zero when EBIT is zero. As EBIT increases, EPS increases $\$ 0.50$ for each $\$ 1$ million rise in EBIT. With $\$ 100$ million of debt, the line starts with a negative $\$ 10 \mathrm{EPS}$; at this point, EBIT is zero, but JBC still has to pay $\$ 10$ million of interest expenses. The result is a loss of $\$ 10$ million. Divided by 1 million shares, this loss produces a $\$ 10$ loss per share. When EBIT rises, EPS in- creases twice as fast as when there is no debt, that is, EPS increases $\$ 1$ for each $\$ 1$ million rise in EBIT. The reason should be clear: the number of shares outstanding is reduced by half when the firm borrows $\$ 100$ million to repurchase equity.

Now, consider the point at which the two lines intersect. For values of EBIT less than its value at the intersection point, EPS is higher if JBC selects an all-equity capital structure. At the point at which the lines intersect, EPS is the same for both financing alternatives. For values of EBIT greater than its value at the intersection point, EPS is higher with debt financing.

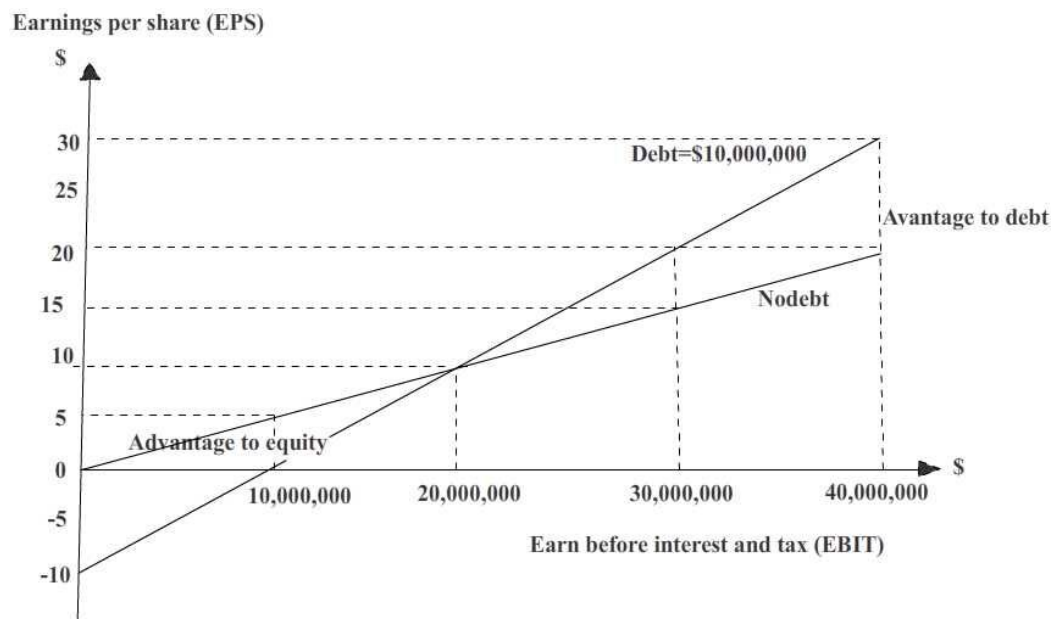

Fig. 1 -JBC's earnings per share under different capital structures 


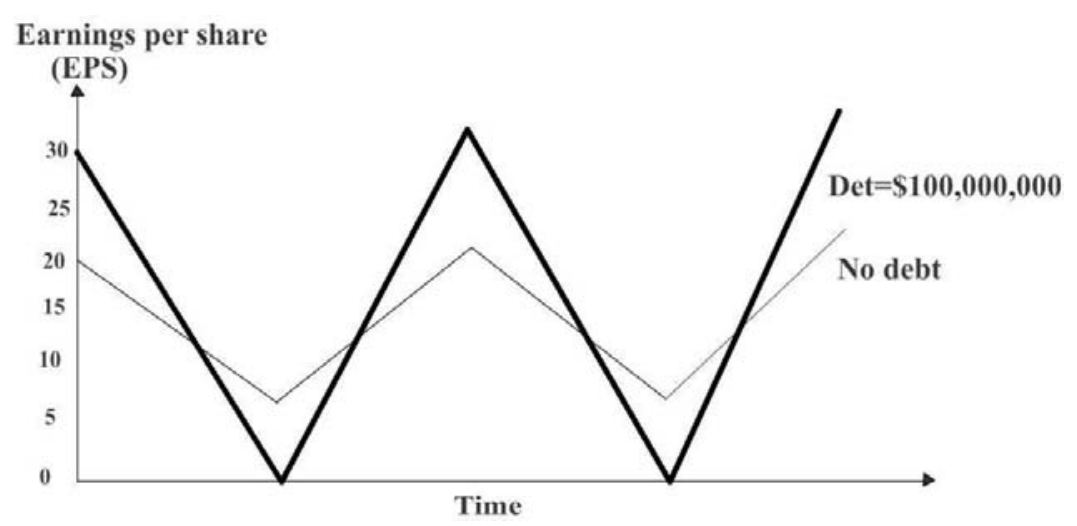

Fig. 2 - Borrowing and risk

Thus, when EBIT equals $\$ 20$ million, EPS is $\$ 10$ for both capital structures. Note that when EBIT is $\$ 20$ million, JBC's return on assets is 10 percent (\$20 mil- lion of EBIT divided by $\$ 200$ million of assets), which is the same as the rate of interest on the debt. As long as JBC earns a return on its assets that is higher than its cost of debt, its shareholders are better off with debt financing. from this analysis, Ms. Johnson can draw the following tentative conclusions: 1. the capital structure decision affects the firm's profitability measured by EPS 2. Financial leverage increases EPS as long as EBIT is higher than $\$ 20$ million, which is the same as saying that return on assets exceeds the 10 percent cost of debt 3. At the $\$ 30$ million expected level of EBIT, EPS are $\$ 15$ with no debt financing and $\$ 20$ with $\$ 100$ million of debt financing clearly, under the expected scenario, borrowing would benefit JBC's share- holders. However, Ms. Johnson knows that she cannot make a decision on the basis of a single scenario. There is some probability that the economy will fall into a reces- sion, in which case borrowing will hurt rather than benefit shareholders. Before Ms. Johnson makes her decision, she must consider the risk that EBIT and return on as- sets are lower than their threshold values of \$20 million and 10 percent, respectively.

The relationship between borrowing and risk is illustrated in the graph shown in Figure 2. The lines represent the changes in JBC's EPS as a function of time for the two capital structures of the last section: no debt financing and \$100 mil- lion of debt financing. EPS is calculated for values of EBIT that vary over time between the recession and the expansion scenarios, that is, between $\$ 10$ million and $\$ 40$ million. In the absence of debt, EPS varies between $\$ 5$ and $\$ 20$, as shown in Table 1 . The variations in EPS result from changes in general economic conditions and from factors affecting the industry to which JBC belongs. The risk generated by these changes, which originates from the business environment in which the firm operates, is rightly called business risk. In the presence of debt, EPS varies between $\$ 0$ and $\$ 30$. The graph in Figure 2 clearly shows that debt financing amplifies the variability of EPS. The extra risk related to this magnifying effect is called financial risk. The MM theory of capital structure provides a starting point for understanding how debt financing affects the firm's value. The theory says that, like a pizza whose size cannot be increased by slicing it, the value of a firm and its share price cannot be increased by changing the proportions [9-10] of debt and equity in its capital structure, provided there are no corporate income taxes. According to this theory, developed by Modigliani and Miller, as the firm increases its financial leverage, the extra benefits accruing to shareholders from higher expected EPS is a compensation for the extra risk brought about by that leverage. Although the cost of equity increases with leverage, the firm's weighted average cost of capital (WACC), and thus the value of the firm's assets, do not change. When corporate income taxes are considered, debt financing is definitely better than equity financing because the annual interest tax shield resulting from the tax deductibility of interest expenses provides value to shareholders.

\section{Summary}

The choice of funds used to finance a firm's investments is important, and certain factors need to be taken into account when designing an optimal capital structure, namely, a capital structure that 
maximizes the firm's value and share price. Our analysis of the capital structure decision begins with how changes in the firm's debt-to-equity ratio affect the firm's profitability, measured by its earnings per share (EPS). By increasing its financial leverage (higher debt ratios), a firm can increase its expected EPS, but it must bear the increasing financial risk (wider swings in EPS) that accompanies higher levels of debt. Unfortunately, the EPS approach to capital structure-although providing useful insights about the capital structure decision - does not identify the ideal trade-off between higher expected EPS and wider fluctuations in EPS. We need to know how debt affects the firm's value.

\section{References}

[1]John Consler, Greg M. Lepak, Susan F. Havranek, Earnings per share versus cash flow per share as predictor of dividends per share, Managerial Finance, 37 (5), 2007.

[2]Ngozi Ben ANUONYE, Intellectual Capital Measurement: Using the Earnings Per Share Model of Quoted Insurance Companies in Nigeria, International Business and Management, 10 (1), 2015, 88-98.

[3]Thomas Zellweger, Roger Meister, Urs Fueglistaller, The outperformance of family firms: the role of variance in earnings per share and analyst forecast dispersion on the Swiss market, Financial Markets and Portfolio Management, 21 (2), 2007, 203-220.

[4]Xiang-li LI, Shao-rong SUN, The Relationship Between the Adjusting Earnings Per Share and the Market Quality Indexes of the Listed Company, Management Science and Engineering, 4 (3), 2010, 55-59.

[5]Ioan Marian Miclăuş, Alexandru Bologa, Ioan Doroş, Liliana Todor, Value created, expression and analyze indicator of an enterprise efficiency, Communications of the IBIMA, 1 (17), 2008, 146.

[6]Azhagaiah Ramachandran, Muralidharan Janakiraman, The Relationship between Working Capital Management Efficiency and EBIT, Managing Global Transitions, 7 (1), 2009, 61.

[7]Thorsten Knauer, Friedrich Sommer, Interest barrier rules as a response to highly leveraged transactions: Evidence from the 2008 German business tax reform, Review of Accounting and Finance, 11 (2), 2012, 206-232.

[8]John R. Graham, Michael L. Lemmon, MEASURING CORPORATE TAX RATES AND TAX INCENTIVES: A NEW APPROACH, Journal of Applied Corporate Finance, 11 (1), 2005.

[9]Daniel C. Funk, Jeffrey D. James, Consumer Loyalty: The Meaning of Attachment in the Development of Sport Team Allegiance, Journal of Sport Management, 20, 2006, 189-217.

[10]James, J. D.; Ross, S. D., Comparing sport consumer motivations across multiple sports, Sport Marketing Quarterly, 13 (1), 2004, 17-25. 